\title{
Harvey Tercentenary
}

\section{WILLIAM HARVEY: THE MAN AND THE GOLLEGE OF PHYSIGIANS \\ By K. D. KEELE, M.D., F.R.G.P. \\ Consultant Physician, Ashford Hospital and Staines Hospital}

IN I578, on I April, Thomas Harvey of Folkestone, and his wife Joan, were blessed with their firstborn of ten children, William Harvey. This birth took place in a 'faire stone-built house' which later became the post office. At the age of ten the young William was sent to the Grammar School (now the King's School), Canterbury, for his elementary education, whence, at the age of sixteen he was entered as a pensioner of Caius College, Cambridge, taking his Arts degree in 1597 and departing the following year, aged nineteen, for Padua, to receive his medical education from the best medical school in Europe. Here he learnt anatomy from Fabricius ab Aquapendente for whom only four years before a new anatomical theatre had been built, in the form of six narrow concentric galleries below which was placed a table for the body. The whole theatre was windowless, and lighting was from two candelabra of three candles each, and eight lamps held by students. During the five years Harvey spent in Padua Fabricius ab Aquapendente was producing for publication his work, De Venarum Osteolis, on the valves in the veins, which was published in 1603 . One may be quite sure, under these circumstances, that these valves were thoroughly demonstrated and discussed in the presence of the student Harvey, and that in conditions of darkness which he found particularly favourable for contemplation of their significance. For Harvey told Aubrey that, 'he did delight in the darke, and he could then best contemplate. He had a house at Combe, in Surrey ... where he had caves made in the earth, in which in summer time he delighted to meditate.' When one adds to these observations Harvey's reply to Robert Boyle's question, that it was the placing of the valves of the veins which first induced him to think of the circulation of the blood, it becomes very probable, as Professor K. J. Franklin has recently suggested, that Harvey returned to England in 1602 with this idea already in mind.

He returned also with a handsome diploma, couched in such grandiloquent language that it has often been claimed that the University of Padua already recognized Harvey's extraordinary ability. Unfortunately the spate of eulogistic praise contained in Harvey's diploma is to be found in other diplomas of the time. J. F. Payne writes, 'Every doctor was said to have 


\section{K. D. Keele}

answered marvellously, and far surpassed the high expectations which had been entertained regarding him. Harvey's Diploma was neither more nor less than the usual one.' In 1764 this diploma, which had found its way back to Harvey's old school in Canterbury, was presented by the Headmaster, Mr. Beauvoir, to the College of Physicians, and is now in the library.

Back in England Harvey received his doctor's degree from the University of Cambridge; after which he came to London and embarked on his professional career. In 1604, in the first year of the reign of James I of England, Harvey married Elizabeth Browne, daughter of Dr. Lancelot Browne, a Fellow of the College, and first physician to Queen Elizabeth I in her last years. The marriage took place at St. Sepulchre's on 24 November. Very little seems to be known about Harvey's wife. They had no children; and appear to have lavished affection on a pet parrot, whose tricks Harvey describes at considerable length in his De Generatione. 'My wife had a beautiful parrot,' he writes, 'a great pet learned and talkative enough, and so tame that it was allowed to roam at liberty about the house ... Full of play and lasciviousness it would frequently sit in its mistresses lap, where it loved to have her scratch its head and stroke its back ... Not long after the caressings mentioned the parrot, which had lived in good health for many years, fell sick, and by and by being seized with repeated attacks of convulsions, seated in the lap of its mistress, it expired, grievously regretted. Having opened the body in search of the cause of death, I discovered an egg, nearly perfect, in the uterus ...' The anecdote provides the only glimpse his writings allow us into his domestic life.

\section{HARVEY'S PERSONALITY}

What kind of man did Elizabeth Browne marry? As Aubrey describes him: 'He was not tall; but of the lowest stature, round-faced, olivaster complexion; little eie, round very black, full of spirit; his haire was black as a raven, but quite white twenty years before he dyed.' The portrait in the hall of the College corresponds closely to Aubrey's description. But the most striking characteristic of Harvey, escaping the arts of sculpture or painting, was that of energy. Aubrey described him in his youth in the following words: 'He was, as all the rest of his brothers, very cholerique; and in his young days wore a dagger (as the fashion then was) but this Dr. would be too apt to draw out his dagger on every slight occasion.' And the Earl of Arundel described him as 'that little perpetual movement called Dr. Harvey'. Obviously a great deal of that energy was directed into his anatomical studies. 'He was always very contemplative,' writes Aubrey, 'and the first that $I$ heare of that was curious in anatomie in England. He had made 


\section{Harvey Tercentenary}

dissections of frogges, toades, and a number of other animals, and had curious observations on them, which papers, together with his goods, in his lodgings at Whitehall, were plundered at the beginning of the Rebellion, he being for the king and with him at Oxon.' This mental activity, preferably in the dark as already mentioned, is again noted by Harvey as a cause of his insomnia. 'He was hott-headed, and his thoughts working would many times keep him from sleepinge; he told me that then his way was to rise out of his bed and walk about his chamber in his shirt until he was pretty coole. ... .' writes Aubrey.

Outside his professional and anatomical studies Harvey's main interests seem to have lain in philosophy, travelling, and the fine arts. His advice on books was 'Go to the fountain head, and read Aristotle, Cicero and Avicenna', and he thought nothing of contemporary writers. When he quotes from 'the poet' as he does on several occasions, he is not referring to his contemporaries, Milton or William Shakespeare, but to Virgil whose works are reported to have moved him 'to throw the book from him with expressions of rapture'. His under-valuation of his contemporaries work is well illustrated with regard to Galileo. In spite of the fact that his demonstration of the circulation of the blood was a mechanical interpretation of events, Harvey persistently ignored Galileo, both the works and the man, even though they were both in Padua, and later Florence, at the same time. Chemistry too he ignored: 'He did not care for chemistrey, and was wont to speake against them with an undervalue,' writes Aubrey.

In politics Harvey was staunchly loyal to the King, Charles I, but that his interest in political affairs was languid would appear from his reading a book at the battle of Edgehill. A similar indifference towards taking an active part in the campaign was shown by his suggestion to Dr. Charles Scarborough in whose conversation we are told he was much delighted; 'and whereas before, he marched up and downe with the army, he tooke him to him and made him ly in his chamber, and said to him, "Prithee leave off thy gunning, and stay here" '. And it was at Oxford in 1642 that Aubrey reports that, 'he came severall times to Trin. Coll. to George Bathurst B.D. who had a hen to hatch egges in his chamber, which they daily opened to discerne the progress and way of generation.'

Personal wealth also does not appear to have interested him much. Although he died worth $£ 20,000$ and made such generous gifts to our College it would appear that this affluence arose as much from the business activities of his brothers, particularly Eliab, as from his own lucrative practice. We are told that, 'for twenty years before he dyed he took no manner of care about his worldly concernes, but his brother Eliab, who was a very wise and prudent manager ordered all not only faithfully, but better than he could have done himself'. 


\section{K. D. Keele}

The few glimpses we can get of Harvey's practice of medicine show a rational caution in treatment greatly in contrast to the therapeutic excesses of his day. For example, when attending Prince Maurice, at Oxford, in I643, Harvey is reported as 'concluding the disease to be venomous he resolved to give very little physic only a regular diet and cordial antidotes'. And Aubrey reports, "All his profession would allow him to be an excellent anatomist, but I never heard of any that admired his therapeutique way. I knew several practisers in London that would not have given $3 d$. for one of his bills; and that a man could hardly tell by one of his bills what he did aim at.'

\section{PHYSICIAN TO ST. BARTHOLOMEW'S HOSPITAL}

In the same year as his marriage Harvey was admitted as a Candidate for Fellowship of the College of Physicians, and he was elected Fellow three years later, in 1607, whereupon he immediately applied for the post of Physician to St. Bartholomew's Hospital, bringing in his support testimonials from King James, Dr. Atkins, President of the College, and other senior Fellows. Perhaps it is not surprising that there were no other applicants. There was only one physician at Bart's in Harvey's time, whose duties were to attend one day in the week at least, 'and cause the Hospitaller, Matron, or Porter to call before you in the hall of the hospital such and so many of the poor harboured in this hospital as shall need the counsell and advice of the physician'; so runs the Charge of the Physician. Unlike the Surgeons, the physician did not go into the wards unless especially asked. Harvey continued these duties regularly until 1630 when he began a series of journeys on behalf of the king which interfered so much with his duties that an assistant physician was appointed. But in 1633 Harvey presented to the Governors a set of 12 orders or articles modifying the organization of the hospital regarding admission, discharge and treatment, of patients. Amongst these was the rule that incurable, 'Scandalous or infectious patients shall be put out of the house or be sent to an outhouse', a rule still I think in force today. He also ruled that 'every Chirurgeon shall shew and declare unto the Doctor, whensoever he shall in the presence of the patient require him, what he findeth and what he useth to every external malady'; a position of inferiority against which the surgeons vigorously protested. Harvey's irregular attendance continued until the middle of the Givil War, 1643, when St. Bartholomew's quietly stopped paying him his annual stipend of $£ 33$ 6s. 8d., and in Parliament Dr. Micklethwaite 'was recommended to the Wardens and Masters of St. Bartholomew's Hospital to be physician in place of Dr. Harvey, who hath withdrawn himself from his charge and is retired to the party in arms against the Parliament.' 


\section{Harvey Tercentenary}

\section{HARVEY, THE KING, AND THE COLLEGE OF PHYSICIANS}

Throughout his life Harvey displayed two great loyalties; to his king, and to the College of Physicians. It has already been noted that from his earliest days in London he made firm friends of both the king and the president of the College. Through all his life these friendships never faltered, and when the king was executed, in 1649 , all Harvey's devotion was turned to the College. In I6r6 Harvey was appointed Lumleian Lecturer, a life appointment which he held to within a year of his death. These lectures, rather unfairly it seems to me, omit the name of their real founder, Dr. Caldwell. In 1579 this doctor, who had the distinction of being admitted to fellowship and appointed a censor of the College on the same day, had proposed to give the Barber Surgeons an annuity for a lecture on Surgery, which they declined. Two years later, this time in conjunction with Lord Lumley, Dr. Caldwell repeated the offer on a more generous scale, not however to the Barber Surgeons but to the College of Physicians. The lecturer was to lecture twice a week throughout the year, reading in Latin for the first three-quarters of the hour, and summarising in English for the last quarter, 'for those that understand not Latin'. The lectures were constructed in cycles of six years. Each year was divided into a winter and summer session; dissections being carried out in a five-day session in the winter, 'if the bodies may last so long without annoy'. In the first year an epitome of the whole art of Surgery, the tables of Horatius Morus, was to be read, with extracts from Galen and Oribasius; and that winter a dissection of the whole body, with particular emphasis on the viscera was to be made. In the second year the reading of other Surgical works was to be followed by dissection of the trunk with particular attention to the muscles. The third year comprised readings on wounds followed by dissection of the head and neck only. The fourth year covered the subject of ulcers, dissection that year being confined to the leg and arm. In the fifth year the works of Paulus Aegineta were read, and in winter the skeleton was demonstrated. In the sixth and last year of the cycle, the works of Holerius on surgery were read.

\section{LUMLEIAN LEGTURES}

When Harvey commenced his series of Lumleian Lectures the College had just moved from Linacre's house in Knightrider Street to Amen Corner, occupying a site where at present the Canons of St. Paul's are resident, and near the bombed north wing of Stationer's Hall. The notes that Harvey made for the first two lectures of the course, i.e. on the viscera and the muscles are still extant in the British Museum. They bear the title, 


\section{K. D. Keele}

Praelectiones Anatomiae Universalis per me Gulielmum Harveium, and they are prefaced by eleven guiding principles. Though all these are good, four in particular Harvey applied all his life; To enforce the right opinion by remarks drawn from far and near, and to illustrate man by the structure of animals; Not to praise or dispraise other anatomists, for all did well, and there was some excuse even for those who are in error; Not to dispute with others, or attempt to confute them, except by the most obvious retort; To state things briefly and plainly, yet not letting anything pass unmentioned which can be seen.

It is in the first lecture of the course, on the viscera, that Harvey describes the circulation of the blood. In his extraordinarily bad handwriting, and in a mixture of Latin and English he writes: 'It is plain from the structure of the heart that the blood is passed continuously through the lungs to the aorta as by the two clacks of a water bellows to raise water. It is shown by the application of a ligature that the passage of the blood is from the arteries into the veins. Whence it follows that the movement of the blood is constantly in a circle, and is brought about by the beat of the heart.'

It was another twelve years before he published that brief tract of seventytwo pages, On the Movement of the Heart and Blood in Animals, in which he keeps so closely to all those rules he set before himself for his Lumleian Lectures. What investigator today would attempt to compress such work into so small a compass?

Another volume of lecture notes consisting of 12 I pages of closely written illegible script, still exists. It is said to represent the lecture on 'Muscles'. I know of two persons at present employed on the task of deciphering this Harveian code, and I feel sure it will not be long before they are presented to the world in comprehensible form.

The formal procedure of these Lumleian lectures was elaborate. According to D'Arcy Power the Council assembled in the parlour to put on their gowns, then the procession entered the theatre, the beadles going first, next the Glerk, then the Doctor, and after him the several gentlemen of the Court; and having come therein, the Doctor and the rest of the company being seated, the Glerk walks up to the Doctor and presents him with a wand and retires. The wand was used, of course, to demonstrate the parts exposed; that used by Harvey has been preserved by the College and is still intact for us to see.

Another relic in the Library, traditionally associated with Harvey's Lumleian Lectures, is the set of anatomical tables, reported to have been made by Harvey himself. They consist of six life-size representations of the vascular and nervous systems. Such anatomical tables were very rare. Apparently they were obtainable in Italy, and only one other set I believe is known in England. Under such circumstances should Harvey have 


\section{Harvey Tercentenary}

prepared or owned them, it is surprising that he should not have mentioned them. They are nevertheless of great interest as examples of 17 th century methods of teaching Anatomy.

During the decade $1620-30$ Harvey steadily ascended the scale of dignities, both at Court and in the College. From his appointment as Physician Extraordinary to King James I, he rose to Physician in Ordinary to King Charles I, who remained Harvey's friend as long as he lived. He became a Censor to the College in $161_{3}, 1_{625}$, and 1629 , during which he examined and passed one James Primrose who thereupon went into practice at Hull and became Harvey's most abusive opponent. In 1628, the year of publication of De Motu Cordis, Harvey was made Treasurer of the College, and again in 1629 , but at the end of this year, after a sumptuous banquet he asked his colleagues to release him on account of the King's commanding him to accompany the Duke of Lennox abroad. Harvey's interest in the journey is betrayed in a letter to Viscount Dorchester; 'I can only complain that by the way we could scarce see a dog, crow, kite, raven or any other bird, or anything to anatomise, only some few miserable people, the relics of the war and the plague where famine had made anatomies before I came.'

In 1632 Harvey was back in England drawing up a set of rules for the Library of the College of Physicians. In 1633 he was off again on another journey, this time with Charles I to Scotland. Once more the Harveian record of this vitally important political mission is characteristic; it consists of a detailed description of the seabirds on the Bass Rock.

Soon after his return to London Harvey became involved in the affair of the Lancashire witches. This all arose on account of an imaginative lad of ten claiming that he saw two dogs turn into a woman and a boy. The woman asked him to sell his soul to the devil, and when he refused turned the little boy into a horse on which she mounted with the narrator in her arms. After flying over fields and bogs they landed by a barn in which they found seven old women who provided a magic feast; all these women the boy named. The whole group of them were brought to London for examination by midwives, under instructions by Dr. Harvey. One woman confessed to being a witch, but in spite of this, she, and three others appear to have been pardoned; the remaining three died in gaol.

\section{HARVEY'S TRAVELS}

Two years later in 1636 , Harvey accompanied Thomas Howard the second Earl of Arundel on his mission to the Emperor Ferdinand II in Vienna. Between Maintz and Frankfurt the Ambassador's party was made very anxious by the activities of Freebooters in the region, who, writes Coryat, 'are such cruel and bloody horseleaches . . . that they seldom robbe 


\section{K. D. Keele}

any man but forthwith they cut his throat. And some of them do afterwards escape by reason of the woode nere at hand. . . . The naturalist, Harvey, was, however, quite oblivious of these dangers, and Hollar reports that 'Dr. Harvey would still be making observations of strange trees and plants, earths, etc., and sometimes he was like to be lost, so that my Lord Ambassador would be really angry with him, for there was not only a danger of thieves but also of wild beasts.'

At Nuremburg Harvey wrote to Caspar Hoffman, Professor of Medicine there. Hoffman had criticised Harvey's suggested circulation of the blood on the grounds that he 'had impeached and condemned Nature of folly and error, and that he had imputed to her the character of a most clumsy and inefficient artificer in suffering the blood to become recrudescent, and making it return again and again to the heart in order to be reconcocted only to grow effete again in the arterial system: thus uselessly spoiling the perfectly made blood merely to find her something to do'. In short he considered the circulation to be a senseless hypothesis. Harvey replied by giving a demonstration in public, but the function of the circulation was a question he never did solve, and he merely demonstrated its existence without answering Hoffman's criticism. The old man remained obdurate on his point, and Harvey is said to have thrown down his scalpel and walked out.

From Linz and onwards Harvey wrote a series of letters to Lord Feilding who had been sent to Venice in 1634, 'ostensibly as Ambassador,' writes D'Arcy Power, 'but really to collect art treasures in Italy'. These letters from Harvey were found in I9I I amongst the manuscripts of the Earl of Denbigh (Feilding himself being the second Earl of Denbigh); they were bought by Sir Thomas Barlow and presented to the College. From them it emerges that Harvey left the Earl of Arundel at Augsburg to visit Lord Feilding in Venice in order to execute a commission for the King concerned with the collection of art treasures. Harvey ran into trouble at Treviso with his health passport, and was confined for nearly three weeks in the lazaretto there on suspicion of being a plague contact. His anger was intense, and it permeates six long letters to Lord Feilding. Things were made no better for him by an attack of sciatica. The letter from Florence in September shows him in a far happier frame of mind: 'Since I came safe to Florence, I have seen this fayer city and enjoyed much contentment therein, with health and mirth.' Thence he went to Rome where he met his friend Dr. George Ent, returning to join the Earl of Arundel in November at Ratisbon. On the journey back to England vast purchases of art treasures were made, particularly at Nuremburg where two pictures by Albrecht Dürer, and the famous Pirkheymer library were purchased. It is known that the greater part of the Earl of Arundel's magnificent collection of manuscripts was obtained on this occasion, and it is possible that they included some of the 


\section{Harvey Tercentenary}

Leonardo drawings which came to light in this country over a century later. In 1639 Harvey was appointed senior Physician in Ordinary to the King. This appointment carried with it a lodging in Whitehall. It also meant that Harvey travelled with the King on those journeys to Scotland necessitated by the formation of the Covenant and military acts of rebellion on the part of the Scots. Nevertheless Harvey found time to obtain permission from the College to sue the heirs of Baron Lumley for the salary of the Lumleian lecturer. This suit he renewed in 1647 when the Givil War was over, but it remained unsettled at the time of his death.

\section{GIVIL WAR}

When the King raised the standard at Nottingham in 1642 it spelt personal tragedy for Harvey. For the Parliament troops in London ran riot in Whitehall and Harvey's lodgings were rifled, his specimens and papers destroyed. 'I remember,' writes Aubrey, 'I have heard him say he wrote a booke $D e$ Insectis, which he had been many yeares about, and had made curious researches and anatomical observations on them. This booke was lost when his lodgings at Whitehall were plundered in the time of the rebellion. He could never for love nor money retrieve them or heare what became of them and said 'twas the greatest crucifying to him that ever he had in all his life.' Harvey describes the event in milder terms. 'Certain rapacious hands not only stripped my house of all its furniture, but what is subject of far greater regret to me, my enemies abstracted from my museum the fruits of many years of toil. Whence it has come to pass that many observations, particularly on the generation of insects, have perished, with detriment, I venture to say, to the republic of letters. Let gentle minds forgive me, if recalling the irreparable injuries I have suffered, I here give vent to a sigh.'

At the Battle of Edgehill Harvey behaved in characteristic fashion. During the fight, the prince and the Duke of York (i.e. the future Kings, Charles II and James II) were committed to his care. 'He told me,' writes Aubrey, 'that he withdrew with them under a hedge, and took out of his pockett a booke and read; but he had not read very long before a bullet of a great gun grazed the ground near him, which made him remove his station.'

A week later the King entered Oxford in triumph. Here Harvey at once found many congenial minds, and within six weeks was awarded his Doctorate. For four years, until 1646 , throughout the Civil War, he appears to have been engaged in his professional duties, and as we have already seen, found time to study the development of the chick in the egg. Here he made contact with such men as Willis and Wren, founders of the Royal Society in years to come. In 1645 he was elected Warden of Merton College. But within a year 


\section{K. D. Keele}

King Charles was carried off into captivity, and Harvey returned to London to find shelter with his wealthy brothers, Daniel and Eliab, the latter having a town house, first in Poultrey, and then Cockaine House in Broad Street, as well as country residences at Roehampton and Rolls Park, whence the pictures of the Harvey family in the entrance hall of the College have been temporarily acquired. Harvey also had rooms in his brother Daniel's house in Lambeth and Combe, near Croydon. Here it was 'he had caves made in the earth in which in summer time he delighted to meditate'.

Harvey was now an old man of 68, and his health was beginning to fail as manifested by gout and arteriosclerosis. To gout Aubrey attributes that pain in his legs for which 'his way of cure was thus; he would sit with his legges bare, if it were frost, on the leads of Cockaine House, put them into a payle of water, till he was almost dead of cold, and betake himself to his stove, and so 'twas gone'. This pain, in his last years became such a problem that Dr. Scarborough who was looking after him apparently had to use opium in large doses.

\section{HARVEY'S LATER YEARS}

In 1649 , in his seventy-first year Harvey allowed himself his first public reply to the many criticisms of his De Motu Cordis. He was stimulated to this by the publication in the previous year of a work by John Riolan of Paris, who made partial concessions to Harvey's thesis, but held that there were parts of the body in which circulation of the blood did not occur. Harvey's reply is so cogent and closely argued that it leaves no doubt of the vigour of his mental powers. It is refreshing to see him publishing this 'anatomical disquisition' as from William Harvey, an Englishman, and in the very year of King Charles execution, emphasising his appointment as Principal Physician to His Most Serene Majesty The King.

It was at Christmas the following year (1650) that Dr. Ent describes his visit to 'that great man, the chief honour and ornament of our College, Dr. William Harvey, then dwelling not far from the city'. 'I found him,' writes Ent, 'Democritus like, busy with the study of natural things, his countenance cheerful, his mind serene . . From this meeting Dr. Ent emerged triumphant with the manuscript of De Generatione Animalium in his hands, gladly charging himself, as he puts it 'with the whole business of correcting the press'. So successful was he in this that the book was published within a year, in 1651 .

Harvey now turned his attention almost exclusively to the welfare of the College of Physicians. At an extraordinary comitia held in July $165^{1}$ the President Dr. Prujean asked an unusual question. 'If I can procure one that will build us a library, and a repository for simples and rarities, such as one as will be suitable and honourable to the College, will you assent to have it 


\section{Harvey Tercentenary}

done or no?' Throughout the year $165^{2}$, though building was active, no mention of the benefactor was made. But in February of the following year there appeared, 'a noble building of Roman architecture (of rustique worke, with Corinthian pillasters) at the Physitians' College aforesaid, viz, a great parlour, a kind of Convocation house, for the Fellowes to meet in belowe; and a library above. ...' Aubrey's description of this generous gift. When the doors were thrown open, Harvey himself received his colleagues in the new parlour, and immediately made over to the College the title deeds of the building. In the library he placed all those books which had survived the ransacking of his lodgings in Whitehall. In the museum there were 'numerous objects of curiosity and a variety of surgical instruments'. This Harveian Museum and Library was built to the west side of the College in the garden.

In 1654, Harvey in his absence was elected President of the College, the comitia being prorogued to the next day, when he declined the honour on grounds of ill-health.

In 1656 he resigned his Lumleian lectureship, the duties of which he had conscientiously carried out to the last, and as a gift to the College he gave over his patrimonial estate at Burmarsh in Kent, worth $£ 5^{6}$ a year, in order to institute an annual dinner at which a Latin oration should be spoken, a gratuity for the orator, and provision for the keeper of the library and museum being made. The oration, Harvey directed, should be a commemoration of the benefactors of the College, and an exhortation to Fellows and Members of the College, 'to search out and study the secrets of Nature by way of experiment, and also for the honour of the profession to continue in mutual love and affection amongst themselves'-an appeal singularly appropriate to our present circumstances.

About ten o'clock on the morning of 3 June 1657 Harvey tried to speak, and we are informed 'found he had the dead palsey of his tongue; and he sawe what was to become of him, he knew there was then no hopes of his recovery, so presently he sends for his young nephews to come to him, to whom he gives one his watch ('twas a minute watch with which he made his experiments); to another, another remembrance, etc. made sign to Sambroke, his apothecary (in Black-Fryars) to lett him blood in the tongue, which did little or no good; and so he ended his dayes'. Thus Harvey, like so many geniuses of intellect, died of cerebral haemorrhage. Some three weeks later the funeral procession started from London on its long journey to Hempstead, near Saffron Walden in Essex. About two years before, Harvey's rich brother Eliab had built, on the North side of Hempstead Church, the Harvey Chapel, beneath which is the vault. By 1657 it already contained Harvey's young nieces, between whose bodies, coffinless and lapt in lead, his body was also laid. There the body remained, neglected for two hundred years, until Sir Benjamin Ward Richardson, noting a large fissure in the 


\section{K. D. Keele}

lead, equipped himself with a small mirror and a strip of magnesium to perform what might be called 'sarçophogoscopy', but without success. It was then suggested that Harvey's remains should be interred in Westminster Abbey, but this fell through on account of the death of the Dean of Westminster. In 1882 the tower of Hempstead Church collapsed, fortunately doing no harm to the Harvey vault. This accident stimulated the College of Physicians to appoint a committee to decide upon some further action. Finally the lead case containing Harvey's remains was placed, in the presence of the President and many Fellows of the College, in a marble sarcophagus in the Chapel, where it now lies.

Harvey's generosity to the College he loved so well, was extended into his will. 'Touching my books and household stuff, pictures and apparell of which I have not already disposed I give to the College of Physicians all my books and papers and my best Persia long carpet, and my blue satin embroidered cushion, one pair of brass And-irons with fire shovel and tongs of brass for the ornament of the meeting room I have erected for that purpose. Item, I give my velvet gown to my loving friend Mr. Doctor Scarborough desiring him and his loving friend Mr. Doctor Ent to look over those scattered remnants of my poore library, and what books, papers or rare collections they shall think fit to present to the College, and the rest to be sold, and with the money buy better.'

Most of these relics of Harvey were, of course, lost in the fire of 1666 , but the portrait in the library by Cornelius Jansen was rescued, and amongst the books saved was Harvey's copy of Fallopius' great anatomical work, containing a number of marginal notes and initialled passages. The bust of Harvey in the entrance hall was presented by Dr. Mead in I 739; it is said to be by Peter Scheemakers whose statue of Shakespeare was set up in Poet's Corner, Westminster Abbey, also at the instigation of Richard Mead, a year later, in 1740.

\section{HARVEY'S WORKS}

Of Harvey's works there is time only to make an enumeration. All his known works were published in a fine edition in 1766 by the College of Physicians, in Latin. It contains Harvey's famous works on The Movement of the Heart and Blood, and that On the Generation of Animals, besides the two Anatomical Disquisitions on the Circulation of the Blood, addressed to John Riolan of Paris. With these are six letters on the circulation and on the work of Aselli, Pecquet, and Bartholin on lacteals. Harvey's short account of the Anatomical Examination of the Body of Thomas Parr is the only pathological study we have from his pen.

Of his unpublished works, Harvey's manuscript notes for the Lumleian Lectures, the Praelectiones Anatomiae Universalis, are in the British Museum. 276 


\section{Harvey Tercentenary}

Once in the library of Sir Hans Sloane, by whom they were left to the nation in 1754 , they were later lost, apparently irretrievably, until they reappeared amongst some ignored books in 1876 . In the meantime, in 1850 , Sir George Paget had published the first known letter of Harvey, one to Dr. Ward of Cambridge, concerning a skull. Its characteristic handwriting gave the first information that the manuscripts discovered in the British Museum were indeed in Harvey's own hand. A facsimile reproduction of them was made by the College of Physicians.

A number of Harvey's treatises are known to have been lost either in the ruins of his lodgings in Whitehall, or in the destruction of the College of Physicians in the Fire of London. They include a 'Treatise on Respiration', mentioned in De Motu Cordis, 'Observations on the Function of the Spleen', also mentioned in De Motu Cordis, and the 'Anatomia Medicalis'. This work is mentioned in Harvey's letter to John Riolan. ' $I$ also intend', he writes, 'putting to press my Medical Anatomy or Anatomy in its application to Medicine ... that I may relate from the many dissections I have made of the bodies of persons diseased ... how and in what way the internal organs were changed in their situation, size, structure, figure, consistency, and other sensible qualities, from their natural forms and appearances, such as they are usually described by anatomists'. Could we but find this work we might well discover that Harvey deserved the laurels we award to the great pathologist Morgagni.

Harvey does not appear to have left much impression outside the world of medicine. Evelyn and Pepys mention him only in the most casual manner. Dryden gives him a few insipid lines of poetry, and Cowley a witty ode. The search for all kinds of references to Harvey has been so keen that further finds are hardly to be expected. Yet only last year a poem written by a doctor, and published in Harvey's lifetime has been found by Dr. Poynter of the Wellcome Historical Medical Library. The author, John Collop, M.D., appears to have escaped both medical and literary recognition, yet his book of poems is dedicated to the Marquis of Dorchester who left his library to our College, and John Drinkwater commented that some halfdozen lyrics seem to stand with the very best of seventeenth-century poetry.

May I conclude with a few lines from Dr. Collop's poem 'On Dr. Harvey'.

What, can one pillar onely be thy due,

The Colledge pillar, and truth's pillar too? . . .

All truths before thine, did like heat-drops fall,

Vanish'd so soon scarce seen or known at all.

Thou set'st up sail, swims through the purple flood,

Which blush'd before, 'cause never understood.

Thou circlest through our Microcosm, and we

Learn more than th' world, our selvs, new worlds by thee. . . . 


\section{K. D. Keele}

Those lesser stars, a Peckquet, Bartholine,

Lose all their glory, when by't vy'd with thine;

They babes in Physick by thy milk may please,

Thou open'st veins for cure of truth's disease. . . .

What need we pillars unto Harvey raise, Who rears himself a Pyramid of praise?

To issue wanting Absalom's Pillars rear,

Each generation will give him an heir.

While drops of blood can channel in a vein,

Truths bloody victory will him trophies gain.

\section{REFERENCES}

Aubrey, J. (1898). Brief Lives. Edited by Andrew Clark, Oxford.

FrankLIN, K. J. (1948). William Harvey-a speculative note. Gesnerus, 5, 70-4.

Mun K, W. (1878). Roll of the Royal College of Physicians of London. London.

PAyne, J. F. (1908). Notes to accompany a Facsimile Reproduction of the Diploma of Doctor of Medicine, granted by the University of Padua to William Harvey.

Power, D'A RCY (1897). William Harvey. London.

- (1931). Selected Writings, 1877-1930. Oxford.

Poynter, F. N. L. (1956). An Unnoticed Contemporary English Poem in Praise of Harvey and its Author, John Collop, M.D. J. Hist. Med., II, 374-83. 